\title{
Arginase Inhibitory Activity and Total Flavonoid Content on Caesalpinia ferrea C. Mart Stem Bark Extracts
}

\author{
Devi Indriani, Berna Elya*, Arikadia Noviani
}

\section{Devi Indriani, Berna Elya*,} Arikadia Noviani

Department of PharmacognosyPhytochemistry, Faculty of Pharmacy, Universitas Indonesia, Depok 16424 West Java, INDONESIA.

\section{Correspondence}

\section{Berna Elya}

Department of PharmacognosyPhytochemistry, Faculty of Pharmacy, Universitas Indonesia, Depok 16424 West Java, INDONESIA.

Phone no : +62 81314161497

E-mail: berna.elya@farmasi.ui.ac.id

\section{History}

- Submission Date: 29-11-2017;

- Review completed: 14-02-2018;

- Accepted Date: 03-05-2018

\section{DOI : 10.5530/pj.2018.6.202}

Article Available online http://www.phcogj.com/v10/i6

\section{Copyright}

(C) 2018 Phcog.Net. This is an openaccess article distributed under the terms of the Creative Commons Attribution 4.0 International license.

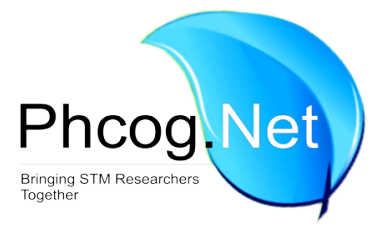

\begin{abstract}
Background: Flavonoids, polyphenolic compounds that are ubiquitous in nature, have been known for their pharmacological as antifungal, diuretic, antihistamin, antihypertension, insecticide, bactericide, antiviral, antioxidant, and enzim inhibitor. Flavanones found in all parts Scutellaria indica, has the ability to inhibit arginase, flavanols found in the seeds of Theobroma cacao L. Previous study showed that Caesalpinia ferrea C. Mart stem bark contains flavonoid compound. Objective: The objective of this study to analyze arginase inhibitory activity and to determine the total flavonoid content of Caesalpinia ferrea C. Mart stem bark by using $\mathrm{AlCl}_{3}$ colorimetric method. Methods: Dried Caesalpinia ferrea stem barks were refluxed with three different solvent with gradual gradient polarity i.en-hexane, ethyl acetate, and methanol. Each extract was tested to determine arginase inhibitory activity. Total flavonoid content was determined on extract showed the highest arginase inhibitory activity. Results: Methanolic extract showed arginase inhibitory activity of $12.81 \%$ and flavonoid content was $2 \mathrm{mgOE} / \mathrm{g}$. Phytochemical screening on Caesalpinia ferrea stem bark ethyl acetate extract showed that it contains flavonoids, tannins, saponins, steroids, and terpenoids, meanwhile Caesalpinia ferrea stem bark methanolic extract contains flavonoids, tannins, saponins, and steroids. Conclusion: Caesalpinia ferrea C. Mart stem bark extracts were not potential to inhibit arginase. Key words: Arginase, Caesalpinia ferrea C. Mart, Flavonoids.
\end{abstract}

\section{INTRODUCTION}

Polyphenols, a secondary metabolite found in fruits, vegetables, and herbs, are widely used to treat chronic diseases such as cardiovascular disease, obesity, diabetes and cancer. ${ }^{1}$ The compound has the ability to increase the activity of NOS (nitric oxide synthase). Increasing the production of NO (nitric oxide) by inbiting the arginase enzymes in mammals. ${ }^{2}$ The increased NO (nitric oxide) in blood vessel cells has an important role in inhibiting platelet aggregation, leukocyte adhesion and infiltration into blood vessel walls, and proliferation of smooth muscle cells of blood vessels. ${ }^{3}$ Previous study showed some active compounds from plants having arginase inhibitory activity that are polyphenols ${ }^{4}$ such as chlorogenic acid, piceatannol, resveratrol, and flavonoids. ${ }^{5}$

Flavonoids are one of the polyphenolic compounds that widely found in almost every green plant. Flavonoids structure of flavonoids has 15 carbon atoms consisting two aromatic rings (ring A and ring B) connected with three carbon units. ${ }^{6}$ Flavonoids exist in all parts of the plant such as leaves, roots, wood, bark, flowers, fruits, and seeds. Pharmacological studies of several flavonoid compounds have shown their ability to serve as antifungal, diuretic, antihistamine, antihypertensive, insecticides, bactericidal, antiviral, antioxidant, and inhibit enzymes. ${ }^{7}$
Flavonoid compounds has the ability to inactivate enzymes by hydrolizing glycosides into active aglycons. ${ }^{8}$ Flavanones found in all parts Scutellaria indica, ${ }^{9}$ has the ability to inhibit arginase, flavanols found in the seeds of Theobroma cacao $\mathrm{L} .{ }^{10}{ }^{10}$ quercetin, and kuersitrin. ${ }^{11}$ More hydroxyl groups in the $\mathrm{B}$ ring flavonol, can increased activity of arginase inhibition. ${ }^{12}$ Arginase inhibitor compounds include boric acid derivatives (S- (2-boronoethyl) -L-cysteine (BEC) and 2- (S) -amino-6-boronohexanoic acid (ABH)) and one of arginine analog compound that is $\mathrm{N}$ (omega) -hydroxy-nor-L-arginine (nor-NOHA). However, BEC and $\mathrm{ABH}$ are potentially toxic and have some pharmacokinetic problems. ${ }^{13}$ As for norNOHA has a very short half-life. ${ }^{14}$ Thus, a better compound to serve as arginase inhibitor is required. It expected to foundant arginase inhibitors from natural ingredients. ${ }^{15}$

Studies about arginase inhibitory activity had been performed on ethyl acetate extract from Caesalpinia sappan showing effect of inhibition with $\mathrm{IC}_{50}$ value equal to $36.82 \mu \mathrm{g} / \mathrm{mL}^{16}$ Other studies showed that Caesalpinia ferrea C. Mart contains flavonoids, saponins, tannins, coumarin, steroids and phenolic compounds. ${ }^{17}$ Some of the pharmacological activities known from Caesalpinia ferrea extracts, anti-inflam- 
matory activity, ${ }^{18}$ antimicrobial, ${ }^{19}$ cancer chemopreventive, ${ }^{20}$ antiarrhythmics, are vasoleraksan ${ }^{21}$ and also used for peptic ulcers treatment. ${ }^{22}$ Thus, based on above description, this study aim to conduct arginase inhibitory activity test and determination of total flavonoid content on Caesalpinia ferrea C. Mart stem bark extracts.

\section{MATERIALS AND METHODS}

\section{Materials}

This study used the stem bark of Caesalpinia ferrea C. Mart obtained from the Center for Conservation of Plants- Bogor Botanical Gardens, nor-NOHA acetate (Cayman, USA), quercetin (Sigma Aldrich, India), arginase, L-arginine, maleic acid, $\mathrm{MnSO}_{4}$ (Sigma Aldrich, Singapore), urea kit assay (Abnova, Taiwan), solvents, total flavonoid content determination reagents, and phytochemical screening reagents.

\section{Preparation of Caesalpinia ferrea C. Mart stem bark extract}

Stem bark of Caesalpinia ferrea C. Mart was collected in December 2016, obtained and identified by the Center for Conservation of Plants- Bogor Botanical Gardens.

\section{Extraction}

Dried powdered of stem bark (150 g) was extracted by using reflux method using three solvent having gradual polarity i.en-hexane, ethyl acetate, and methanol, then evaporated.

\section{Determination Arginase Inhibitory Activity}

The determination of arginase inhibitory activity was determined by using methods made by Sigma Aldrich with some modification in subtrate and enzyme concentration. Mixture of $15 \mu \mathrm{L}$ of arginase $1 \mathrm{U} / \mathrm{mL}$, $20 \mu \mathrm{Lof} \mathrm{L}$-arginine $570 \mathrm{mM}$, and $10 \mu \mathrm{L}$ of sample solution were incubated at $37^{\circ} \mathrm{C}$ for $30 \mathrm{~min}$. After preincubating, $100 \mu \mathrm{L}$ of kit urea assay was added and incubated at room temperature for an hour. Arginase activity was determined by microplate reader (Epoch, USA) at $\lambda 430 \mathrm{~nm}$ by measuring the quantity of urea released from arginase. Each sampels were made blank with added the enzyme after kit urea assay. Nor-NOHA was used as a positive control of arginase inhibitor. The arginase inhibitory activity was defined as $\mathrm{IC}_{50}$ value.

\section{Determination of Total Flavonoid Content}

Determination of total flavonoid content was conducted on extract having highest arginase inhibition. The method refers to the second method listed in Pharmacopoeia Herbal Indonesia Suplement II. Quersetin was used as standart is used to make calibration curves with final concentrations $3,4,5,6,7$ and $8 \mu \mathrm{g} / \mathrm{mL}$ in ethanol pro analysis. As much as $0.5 \mathrm{~mL}$ sample solution of quercetin or extract was added to test tube, then $1.5 \mathrm{~mL}$ ethanol pro analysis was added; $0.1 \mathrm{~mL} \mathrm{AlCl}_{3} 10 \%$; $0.1 \mathrm{~mL}$ of $1 \mathrm{M}$ sodium acatate and $2.8 \mathrm{~mL}$ of distillate water. The volume of $\mathrm{AlCl}_{3} 10 \%$ was replaced by the same quantity of the same volume as the sample blank. The mixture was centrifugate and incubated at room temperature for $30 \mathrm{~min}$. The absorbance was measured by using a UV-Vis spectrophotometer (Jazco) at $\lambda 437,5 \mathrm{~nm}$. The total flavonoid content on extract was calculated by using $y=a+b x$,so the highest arginase inhibitioncan be calculated.

\section{Phytochemical Screening}

The phytochemical screening consited of alkaloids test (using mayer, dragendroff, and wagner reagents), flavonoids test with willstatter reaction, tannins test with gelatin test and ferrous (III) chloride, saponins test with honeycomb froth test, quinones with $\mathrm{NaOH}$, steroids and triterpenoids with libermann-burchard reagent was performed on ethyl acetate and methanol extract.

\section{RESULTS AND DISCUSSION}

\section{Extraction}

The obtained extracts (Table 1) were tested to measure the arginase inhibitory activity and determination of total flavonoid content was conducted on extract having highest arginase inhibition.

\section{Determination Arginase Inhibitory Activity}

The $\mathrm{IC}_{50}$ value of nor-NOHA acetate is $3,7749 \mu \mathrm{g} / \mathrm{mL}$ (Table 2). The $\mathrm{IC}_{50}$ value of nor-NOHA acetate towards arginase from mouse macrophages listed on product info is $10-12 \mu \mathrm{M}$ or is $3.556 \mu \mathrm{g} / \mathrm{mL}$. This suggested that the nor-NOHA acetate's arginase inhibitory activity had no significant differece compared to previous studies as noted in the product info.

The $n$-hexane and ethyl acetate extract had no inhibitory effect on the arginase enzyme shown as negative result (Table 3 ). Table 3 showed that methanol extract had the highest arginase inhibitory activity that was $12.81 \%$. These results showed a low ability to inhibit arginase due to the less active of the compound, therefore further $\mathrm{IC}_{50}$ calculation was ommited.

\section{Determination of Total Flavonoid Content}

The methanol extract of Caesalpinia ferrea stem bark absorbance was plotted in quercetin calibration curve then the total flavonoid content was calculated. The total flavonoid content was expressed in QE (Quercetin equivalent) which is the amount of milligram equivalent of quercetin in $1 \mathrm{~g}$ of sample. Based on the results, in $1 \mathrm{~g}$ of methanol extract stem bark Caesalpinia ferrea contained $2 \mathrm{mg}$ equivalent quercetin.

Phytochemical Screening

Phytochemical screening result is showed in Table 4.

Table 1: The result of extraction by maceration method.

\begin{tabular}{ccc}
\hline Extracts & Results (gr) & Results (\%) \\
\hline$n$-Hexane & 0.87 & 0.58 \\
Ethyl acetate & 4.93 & 3.29 \\
Methanol & 13.47 & 8.98 \\
\hline
\end{tabular}

Table 2: The IC $_{50}$ of nor-NOHA acetate.

\begin{tabular}{ccc}
\hline Concentration $(\mu \mathrm{g} / \mathrm{mL})$ & Percent Inhibition $(\%) \pm$ SEM & $\mathrm{IC}_{50}(\mu \mathrm{g} / \mathrm{mL})$ \\
\hline 1 & $33.90 \pm 2.860$ & \\
3 & $49.20 \pm 8.914$ & 3.7749 \\
4 & $50.43 \pm 7.304$ & \\
5 & $55.39 \pm 9.638$ & \\
\hline
\end{tabular}

Table 3: The IC ${ }_{50}$ value of $\mathbf{n}$-hexane, ethyl acetate and methanol extract of Caesalpinia ferrea C. Mart Stem Bark.

\begin{tabular}{ccc}
\hline No. & Extract $(100 \mu \mathrm{g} / \mathrm{mL})$ & Percent Inhibition $(\%) \pm$ SEM \\
\hline 1 & $n$ - Hexane & $-37.87 \pm 7.439$ \\
2 & Ethyl acetate & $-23.87 \pm 2.236$ \\
3 & Methanol & $12.81 \pm 0.890$ \\
\hline
\end{tabular}


Table 4: Phytochemical screening of ethyl acetate and methanol extract.

\begin{tabular}{ccc}
\hline Phytochemical Contents & Ethyl acetate extract & Methanol extract \\
\hline Flavonoid & + & + \\
Alkaloid & - & - \\
Tannin & + & + \\
Saponin & + & + \\
Quinone & - & - \\
Steroid & + & + \\
Triterpenoid & + & - \\
\hline
\end{tabular}

\section{CONCLUSION}

Methanolic extract showed $12.81 \%$ arginase inhibitory activity in 100 $\mu \mathrm{g} / \mathrm{mL}$ concentration and contained $2 \mathrm{mgQE} / \mathrm{g}$ flavonoid content. This showed that Caesalpinia ferrea C. Mart stem bark extracts were not potential to inhibit arginase. Phytochemical screening result showed that Caesalpinia ferrea stem bark ethyl acetate extract contained flavonoids, tannins, saponins, steroids, and terpenoids, meanwhile Caesalpinia ferrea stem bark methanolic extract contained flavonoids, tannins, saponins, and steroids.

\section{ACKNOWLEDGEMENT}

The authors are highly thankful to Universitas Indonesia who had given a financial support for this research, particularly for PITTA Research Grants 2017.

\section{CONFLICT OF INTEREST}

The authors declare no conflict of intetrest.

\section{ABBREVIATIONS}

nor-NOHA acetate: N(omega)-hydroxy-nor-L-arginine acetate; AlCl3: Alumunium chloride; QE: Quercertin Equivalent; NOS: Nitric Oxide Synthase; NO: Nitric Oxide; BEC: (S-(2-boronoethyl)L-cysteine); ABH: 2-(S)-amino-6-boronohexanoic acid; UV: Ultra Violet; MnSO4: Manganese (II) Sulfate; $\mathbf{N a O H}$ : Sodium Hydroxide.

\section{REFERENCES}

1. Marquardt K, Watson R. Pholyphenols in human Health and Disease. In Academic Press. 2014: 9-15.

2. Bordage S, Pharm T-N, Zedet A, Gugglielmetti AS, Nappey M, Demougeot C,
Girard-Thernier C. Investigation of Mammal Arginase Inhibitory Properties of Natural Ubiquitous Polyphenols by Using an Optimized Colorimetric Microplate Assay. Planta Med. 2016.

3. Durante W. Role of arginase in vessel wall remodeling. Frontiers in Immunology. 2013;4:1-12.

4. Oboh G, Ademiluyi AO, Ademosun AO, Olasehinde TA, Oyeleye SI, Boligon $A A$, et al. Phenolic Extract from Moringa oleifera Leaves Inhibits Key Enzymes Linked to Erectile Dysfunction and Oxidative Stress in Rats Penile Tissues. 2015.

5. Glisic S, Sencanski M, Perovic V, Stevanovic S. Arginase Flavonoid AntiLeishmanial in Silico Inhibitors Flagged against Anti-Targets. 2016. https://doi. org/10.3390/molecules21050589

6. Markham KR, Andersen OM. Flavonoids : Chemistry, Biochemistry and Applications. 2006.

7. Geissmann T. The Chemistry of Flavonoid Compounds. New York: Pergamon Press; 1962.

8. Zhang H, Tsao R. ScienceDirect Dietary polyphenols, oxidative stress and antioxidant and anti-inflammatory effects. Science Direct. 2016.

9. Won S, To K, Cuong D, Manh T, Min BS. Arginase II inhibitory activity of flavonoid compounds from Scutellaria indica. 2013: 922-926.

10. Schnorr O, Brossette T, Momma TY, Kleinbongard $P$, Keen CL, Schroeter $H$, et al. Cocoa flavanols lower vascular arginase activity in human endothelia cells in vitro and in erythrocytes in vivo. 2008;476:211-5.

11. Roberto E, Maquiaveli C, Pupolin P. Experimental Parasitology The leishmanicidal flavonols quercetin and quercitrin target Leishmania (Leishmania) amazonensis arginase. Experimental Parasitology. 2012;30(3):183-8.

12. Pham T, Demougeot C. The Promise of Plant-Derived Substances as Inhibitors of Arginase. 2015:798-808.

13. Ivanenkov YA, Chufarova NV. Small-molecule arginase inhibitors. 2014;3:65-85.

14. Havlinova Z, Babicova A, Hroch M, Chladek J. (2013). and intratracheal administration to brown Norway rats, 8254;1-9.

15. Girard-Thernier C, T.-N Pham, C. D. The promise of plant-derived substances as inhibitors of arginase. Mini-Reviews in Medicinal Chemistry. 2015;15(10):798808.

16. Shin, Woosung, et al. Arginase Inhibition by Ethylacetate Extract of Caesalpinia sappan Lignum Contributes to Activation of Endothelial Nitric Oxide Synthase. Korean J Physiol Pharmacol. 2011;15:123-8.

17. Vasconcelos C, Maranhao H, Batista T, Carneiro E. Hypoglycaemic activity and molecular mechanisms of Caesalpinia ferrea Martius bark extract on streptozotocin-induced diabetes in Wistar rats. J Ethnopharmacol. 2011;137:1533-41.

18. Carvalho J, Teixeira J, Souza P, Bastos J, D, D. S. F., Sarti S. Preliminary studies of analgesic and antiinflammatory properties of Caesalpinia ferrea crude extract. J Ethnopharmacol. 1996;53:175-8.

19. Sampaio F, Pereira M, Dias C, Costa V. In vitro antimicrobial activity of Caesalpinia ferrea Martius fruits against oral pathogens. J Ethnopharmacol. 2009;124:289-94.

20. Nakamura E, Kurosaki F, Arisawa M, Mukainaka T, Takayasu J. Cancer chemopreventive effects of a Brazilian folk medicine, Juca, on in vivo two-stage skin carcinogenesis. J Ethnopharmacol. 2002;81:135-7.

21. Menezes IAC, Moreira IJA, Carvalho AA, Antoniolli AR, Santos MRV. Cardiovascular effects of the aqueous extract from Caesalpinia ferrea: Involvement of ATP-sensitive Potassium Channels. 2007;47:41-7.

22. Bachi E, Sertie J, Villa N, Katzbraga H. Antiulcer action and toxicity of Styrax camporum and Caesalpinia ferrea. Planta Med. 1995;61:204-7.

\section{GRAPHICAL ABSTRACT}

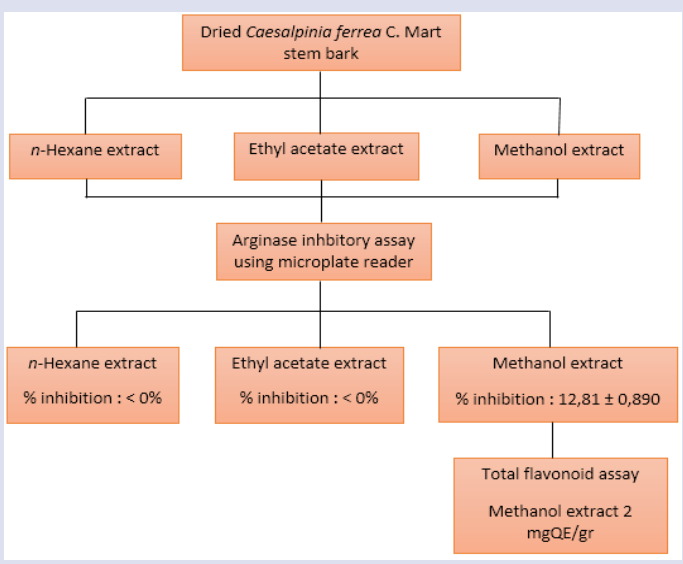

\section{SUMMARY}

- Caesalpinia ferrea C. Mart stem bark were refluxed successively with n-hexane, ethyl acetate, and methanol.

- Methanolic extract showed $12.81 \%$ arginase inhibitory activity in $100 \mu \mathrm{g} / \mathrm{mL}$ concentration and contained $2 \mathrm{mgQE} / \mathrm{g}$ flavonoid content.

- Caesalpinia ferrea C. Mart stem bark extracts were not potential to inhibit arginase. 


\section{ABOUT AUTHORS}

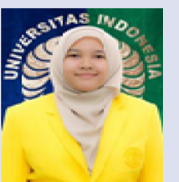

Arikadia Noviani: is a Lecturer and Researcher at Faculty of Pharmacy, Universitas Indonesia. She has expertise in Phytochemistry and Pharmacognocy of Natural Product, working mainly in : Natural Product Isolation and Bioassay.

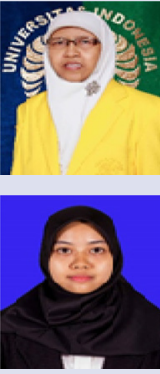

Berna Elya: is a Professor at Faculty of Pharmacy, Universitas Indonesia. She is the Head of Laboratory of Phytochemistry and Pharmacognocy. She has expertise in Phytochemistry and Pharmacognocy of Natural Product, working mainly in : Natural Product Isolation and Bioassay.

Devi Indriani: is a Apothecary student at Faculty of Pharmacy, Universitas Indonesia. Her undergraduate research focused on extraction of natural product and bioassay.

Cite this article: Indriani D, Elya B, Arikadia Noviani. Arginase Inhibitory Activity and Total Flavonoid Content on Caesalpinia ferrea C. Mart Stem Bark Extracts. Pharmacog J. 2018;10(6):1180-3. 